\title{
Respiration and Quality of Fresh-cut Cabbages in Modified Atmosphere Packaging
}

\section{Hu, Wenzhong}

Laboratory of Postharvest Scinece, Division of Bioproduction System Sciene, Department of Bioproduction Environmental Science, Faculty of Agriculture, Kyushu University

Uchino, Toshitaka

Laboratory of Postharvest Scinece, Division of Bioproduction System Sciene, Department of Bioproduction Environmental Science, Faculty of Agriculture, Kyushu University

\section{Nakamura, Takeshi}

Laboratory of Postharvest Scinece, Division of Bioproduction System Sciene, Department of Bioproduction Environmental Science, Graducate School of Bioresource and Bioenvironmental Sciences, Kyushu University

\section{Furuse, Naomi}

Laboratory of Postharvest Scinece, Division of Bioproduction System Sciene, Department of Bioproduction Environmental Science, Graducate School of Bioresource and Bioenvironmental Sciences, Kyushu University

他

https://doi.org/10.5109/24468

出版情報: 九州大学大学院農学研究院紀要. 47 (1)，pp.149-158，2002-10-30. Kyushu University バージョン：

権利関係 : 
J. Fac. Agr., Kyushu Univ., 47 (1), 149-158 (2002)

\title{
Respiration and Quality of Fresh-cut Cabbages in Modified Atmosphere Packaging
}

\author{
Wenzhong $\mathrm{HU}^{\dagger}$, Toshitaka UCHINO, Takeshi NAKAMURA**, \\ Naomi FURUSE**, Daisuke HAMANAKA**, \\ Hussain SOROUR***, Yoshiaki HORI \\ and Shun-ichiro TANAKA
}

\begin{abstract}
Laboratory of Postharvest Science, Division of Bioproduction System Science, Department of Bioproduction Environmental Science, Faculty of Agriculture, Kyushu University, Fukuoka 812-8581, Japan

(Received June 28, 2002 and accepted July 12, 2002)
\end{abstract}

\begin{abstract}
The respiration rates of fresh-cut cabbage were measured by pouch method with 25 and $30 \mu \mathrm{m}$ OPP films in thickness at 5 and $20^{\circ} \mathrm{C}$. The appearance, flavor and ascorbic acid content were also determined during storage. The results indicated that respiration rates of fresh-cut cabbages were suppressed under the condition of decreasing $\mathrm{O}_{2}$ and increasing $\mathrm{CO}_{2}$ concentrations at 5 and $20^{\circ} \mathrm{C}$. It was not found the effects of vertical cutting (VC), parallel cutting (PC) and thickness of film on the respiration at $5{ }^{\circ} \mathrm{C}$. But the respiration rate were much higher in VC treatments than that in $\mathrm{PC}$ treatments, especially for the $\mathrm{CO}_{2}$ production rate at $20^{\circ} \mathrm{C}$ regardless film thickness. The results also showed that a shift from aerobic to anaerobic respiration was occurred under $1.2-1.5 \% \mathrm{O}_{2}$ level. Total ascorbic acid (TAA), ascorbic acid (AA) and dehydroascorbic acid (DHAA) were increased by AA biosynthesis initially and then decreased by higher rate of AA oxidation. Moreover, it was shown the results of sensory evaluation that there were no differences in appearance and flavor for cutting mode and thickness of the film at $5{ }^{\circ} \mathrm{C}$. The better appearance and flavor appeared in VC treatments than PC treatments for cutting mode and thickness of film at $20^{\circ} \mathrm{C}$. It suggests that better quality could be obtained from the combination of $\mathrm{VC}$ treatments and low temperature of $5^{\circ} \mathrm{C}$ regardless of thickness of film.
\end{abstract}

\section{INTRODUCTION}

Fresh-cut or minimally processed fruits and vegetables are a rapidly growing segment of retail and food service horticultural fresh industry (Gorny, et al., 1998). Although fresh-cut products have met the consumers' desire for convenience and freshness, the shelf life is still important challenges for fresh-cut products. There are two basic problems confront the extension of shelf life of fresh-cut fruits and vegetables products. First, processing procedures of cutting cause intermixing of polyphenol oxidase with phenolics which undergo enzymatic browning to product an undesirable brown color (Senesi, et al., 2000). Second, wounding tissue induces a high respiration rate, which triggers faster tex-

** Laboratory of Postharvest Science, Division of Bioproduction System Science, Department of Bioproduction Environmental Science, Graduate School of Bioresource and Bioenvironmental Sciences, Kyushu University

*** Postdoctoral Fellow of Japan Society for the Promotion of Science, Laboratory of Postharvest Science, Division of Bioproduction System Science. Department of Bioproduction Environmental Science, Kyushu University

' Corresponding author (E-mail:huxu@agr.kyushu-u.ac.jp) 
ture deterioration and decrease in nutrients as like ascorbic acid compared to intact tissues (Rosen and Kader, 1989). These lead to a reduced quality and shorter shelf life than that can normally be expected from the fruits and vegetables. To overcome these problems and to have suitable shelf life for fresh-cut product, optimum lower temperature and relative humidity needs to be maintained during whole chain from harvest processing to consumption. The modified atmosphere packaging (MAP) is considered to be the most effective method for extending the shelf life of fresh and minimally processed product by depressing the respiration rate of product and preventing the moisture loss and microbial growth. However, $\mathrm{O}_{2}$ concentration under lower oxygen limit or $\mathrm{CO}_{2}$ concentration over the upper limit of aerobic condition that leads to fermentative metabolism can cause off-flavor and flavor loss (Watada, et al., 1996; Kato-Noguchi, et al., 1997).

A major metabolic process occurring in fresh-cut product is respiration. The respiration rate of product is an excellent indicator of metabolic activity of tissue; that is, it is a useful guide to the potential storage life of the fresh-cuts. But little information is available on respiration rate of fresh-cut cabbage in MAP during the storage and market. The objectives of this study were to determine the respiration rate of fresh-cut cabbage in MAP with two kinds of films in thickness. The evaluation of quality such as ascorbic acid content was also investigated.

\section{MATERIALS AND METHODS}

\section{Plant material}

Cabbages (Brassica oleracea L.) were obtained from the local supermarket in Fukuoka city, Japan. Samples were transported to the laboratory without refrigeration and immediately processed. Cabbages were selected for uniform size and appearance. Outer and damaged leaves were removed.

\section{Cabbage slice preparation}

The cabbages were rinsed with $0.02 \%$ sodium hypochlorite solution to reduce the surface microbial load before cutting. Knife and cutting board were washed and treated with $75 \%$ ethanol prior to use. The cabbage was chopped by hand with a sharp stainless steel knife. The cutting modes were divided into two forms: vertical cutting (VC) and parallel cutting (PC) to vein of cabbage with $2 \mathrm{~mm}$ wide by $5-8 \mathrm{~cm}$ in length. The slices were washed for $6 \mathrm{~min}$ with tap water and then washed with $5^{\circ} \mathrm{C}$ distilled water for $4 \mathrm{~min}$. The slices were centrifuged for $3 \mathrm{~min}$ at $1,720(\mathrm{rpm})$ to remove the water on the cabbage surface by washing machine. And then slices were selected at random and samples of $100 \pm 1 \mathrm{~g}$ were placed in the pouches $(10 \times 20 \mathrm{~cm})$ and heat sealed. A silicone cap was applied on each package to permit analysis of package headspace with a syringe. The void volume in the package was determined by subtracting the volume of fresh-cut cabbage from that of the entire package. The volume of fresh-cut cabbage and the entire package were measured based on water displacement. All processing operations were conducted under $5-8^{\circ} \mathrm{C}$. The film used for cabbage slices packaging was oriented polypropylene (OPP) film (Sumitomo Bakelite Co., Ltd, Tokyo Japan), with two kinds of 25 and $30 \mu \mathrm{m}$ film in thickness. The film permeability was determined by the Akimoto's method (Akimoto, et al., 1997). The pouches were stored at 5 and $20^{\circ} \mathrm{C}$, respectively. 


\section{Gas analysis}

Gas sample was withdrawn by gas-tight $1.0 \mathrm{ml}$ syringe to measure gas composition from the inside the package. The gas concentrations were measured by injecting $1.0 \mathrm{ml}$ gas sample into gas chromatography (GL Sciences GC-390, Tokyo Japan) equipped with thermal conductivity detector (TCD) and D2000 integrator (Hitachi, Ltd. Tokyo Japan). Helium was used as carrier gas and the flow rate was $30 \mathrm{ml} \cdot \mathrm{min}^{-1}$. The injector and column temperatures were 80 and $50^{\circ} \mathrm{C}$, respectively. The column was WG100 with molecular sieve 5 A and Porapak Q 80/100 mesh.

\section{Mathematical model for respiration}

To determine the respiration rate of fresh-cut cabbage under MAP, the basic material balance given in equations can be used (Akimoto et $a l ., 1997$ ). The changes in the free volume of gas within package at the short time were shown in following equations.

$$
\begin{aligned}
& \frac{d V_{S}}{d t}=\frac{d V_{C}}{d t}+\frac{d V_{O}}{d t}+\frac{d V_{N}}{d t} \\
& \frac{d V_{C}}{d t}=\frac{A}{L} K_{C}\left(P_{C a}-P_{C}\right)+R_{C} W \\
& \frac{d V_{O}}{d t}=\frac{A}{L} K_{O}\left(P_{O a}-P_{O}\right)+R_{O} W \\
& \frac{d V_{N}}{d t}=\frac{A}{L} K_{N}\left(P_{N a}-P_{N}\right)
\end{aligned}
$$

where $V$ is the volume of gas in pouch (ml), $A$ is surface area of pouch $\left(\mathrm{m}^{2}\right), L$ is thickness of film (m), $K_{C}, K_{O}$ and $K_{N}$ are the permeability of film for $\mathrm{CO}_{2}, \mathrm{O}_{2}$ and $\mathrm{N}_{2}\left(\mathrm{ml} \cdot \mathrm{m} \cdot \mathrm{m}^{-2} \cdot\right.$ atm $^{-1}$. $\left.\mathrm{h}^{-1}\right), R$ is respiration rate $\left(\mathrm{ml} \cdot \mathrm{kg}^{-1} \cdot \mathrm{h}^{-1}\right), W$ is weight of product $(\mathrm{kg}), P_{C a}, P_{C a}$ and $P_{N a}$ are partial pressure of $\mathrm{CO}_{2}, \mathrm{O}_{2}$ and $\mathrm{N}_{2}$ outside pouch (atm), $P_{C}, P_{0}$ and $P_{N}$ are partial pressure of $\mathrm{CO}_{2}, \mathrm{O}_{2}, \mathrm{~N}_{2}$ inside pouch (atm). These equations show that changes rate of gas volume of package was determined by permeability of film and respiration of product. According to gas partial pressure between internal and external package, this method can be used to determine $\mathrm{CO}_{2}$ production and $\mathrm{O}_{2}$ consumption rates of product based on $\mathrm{CO}_{2}, \mathrm{O}_{2}$ and $\mathrm{N}_{2}$ levels within package. It has been demonstrated that the method is very effective to calculate the respiration rate under steady and unsteady atmospheric conditions.

\section{Sensory evaluations}

Visual appearance and flavor were evaluated by five trained people at cutting and during storage period for every day. Evaluation was carried out in two items of appearance and flavor. They were both scored on 4-point scale: excellent $(-)$; very good $(+)$; fair $(+)$; poor $(H+)$.

\section{Ascorbic acid}

Ascorbic acid content was measured by high performance liquid chromatography (HPLC) equipped with Shim-pack SCR-101N column $(7.9 \mathrm{~mm} \phi \times 30 \mathrm{~cm})$ (Shimadzu 
Corp., Tokyo Japan). The column is packed with a cation exchanger resin which is sulfonated polystylene-divinylbenzene copolymer. The mobile phase was mixed solution of $10 \mathrm{mM}$ oxalic acid dihydrate, $15 \mathrm{mM} \mathrm{N} \mathrm{aH}_{\mathrm{a}} \mathrm{Ond} 1 \mathrm{mM}$ EDTA at a flow rate of $1.0 \mathrm{ml} \mathrm{min}^{-1}$. Temperature is $40^{\circ} \mathrm{C}$ and detector is RI. Cabbage sample was extracted from excised slices of $5 \mathrm{~g}$ cabbage with 5 times the volume of $5 \%$ metaphosphoric acid in a mortar with pestle. The homogenate was filtered through filter paper and centrifuged at 3,000 (rpm) for $15 \mathrm{~min}$. The supernatant was taken as sample to measure the ascorbic acid in cabbage.

\section{RESULTS AND DISCUSSION}

\section{Respiration rate}

Changes in respiration rate, respiratory quotient $(R Q)$ and gas concentration of fresh-cut cabbage in VC treatments were shown in Fig. 1. The changes in respiration rate was approximately same at the conditions of increasing $\mathrm{CO}_{2}$ and decreasing $\mathrm{O}_{2}$ concentrations for 5 days storage at $5{ }^{\circ} \mathrm{C}$ (Fig. $1 \mathrm{~A}$ and $1 \mathrm{~B}$ ). The respiration rates were slightly decreased in MAP during storage of 5 days. There was no significant difference between the two kinds of 25 and $30 \mu \mathrm{m}$ thickness films in depressing respiration during storage period. The ratio of $\mathrm{CO}_{2}$ productd to $\mathrm{O}_{2}$ consumed, known as $\mathrm{RQ}$, is normally assumed to be equal to 1.0 if the metabolic substrates are carbohydrates. In the present study, RQ was fluctuated around 1.0, indicating that anaerobic respiration did not occur for 3-day storage. The $\mathrm{O}_{2}$ concentration continued to decrease and a certain point of $\mathrm{O}_{2}$ concentration was reached, $\mathrm{O}_{2}$ consumption rates were remarkably decreased and $\mathrm{CO}_{2}$ production rates were increased conversely. It was indicated a shift to anaerobic respiration confirmed by higher $\mathrm{RQ}$ values at $1.2-1.5 \% \mathrm{O}_{2}$ levels. This effect of $\mathrm{O}_{2}$ concentration was more marked at higher temperature (Fig. $1 \mathrm{C}$ and $1 \mathrm{D}$ ). At $20^{\circ} \mathrm{C}$, respiration rates were suppressed markedly with quickly increasing $\mathrm{CO}_{2}$ and decreasing $\mathrm{O}_{2}$ levels at first 1 day, and then shift from aerobic to anaerobic respiration occurred with higher RQ at $1.2-1.5 \%$ $\mathrm{O}_{2}$ levels. It was also demonstrated by off-flavor of fermentation when the package was opened for sensory evaluation. For changes in gas concentrations, $\mathrm{O}_{2}$ level was decreased and $\mathrm{CO}_{2}$ level was increased quickly at initial period and then $\mathrm{CO}_{2}$ level was increased slowly and $\mathrm{O}_{2}$ level was reached about $1.2-1.5 \%$, indicating that $\mathrm{O}_{2}$ and $\mathrm{CO}_{2}$ levels were regulated by product respiration and permeability of film during storage (Fig. 1A-1D). The results suggest that MAP could be used as a cheap and easy method to extend the storage life of fresh-cut cabbage.

Changes in respiration rate, $\mathrm{RQ}$ and gas concentration of fresh-cut cabbage in PC treatments were shown in Fig. 2. The trends of changes in respiration rate were similar to the results of VC treatments (Fig. 1). It was also indicated that the thickness of film has less effect on the changes in gas concentration and respiration of fresh-cut cabbages. The storage life of horticultural products has well been related to the respiration rate of products, the suppression of respiratory metabolism will extend the shelf life of stored fresh product (Lopez-Briones, et al., 1992; Kader, 1986). But $\mathrm{O}_{2}$ and $\mathrm{CO}_{2}$ levels beyond its tolerance limits can induce anaerobic respiration and $\mathrm{CO}_{2}$ damage to result in browning and development of off-flavors. It was suggested that better keeping quality for fresh-cut cabbages could be obtained from low $\mathrm{O}_{2}$ storage atmosphere above 1.2-1.5\% lower limit 


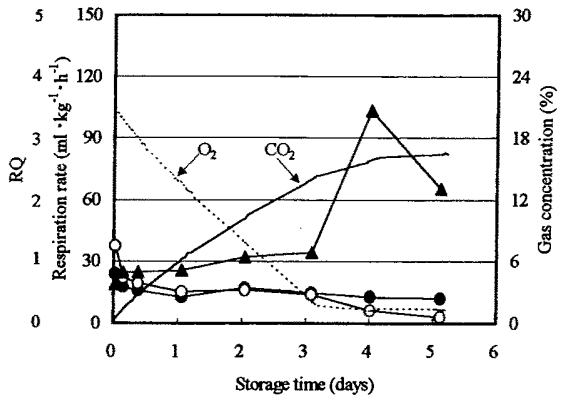

A: $25 \mu \mathrm{m}$ film at $5^{\circ} \mathrm{C}$

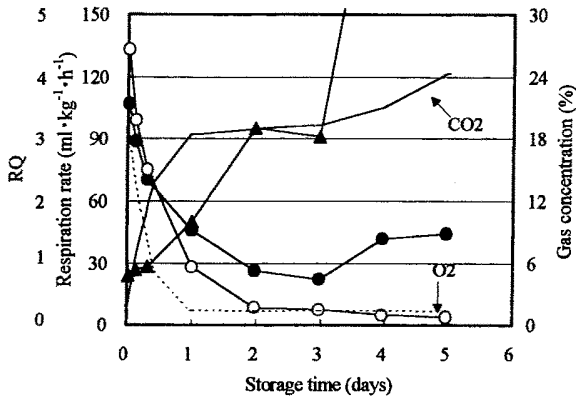

C: $25 \mu \mathrm{m}$ at $20^{\circ} \mathrm{C}$

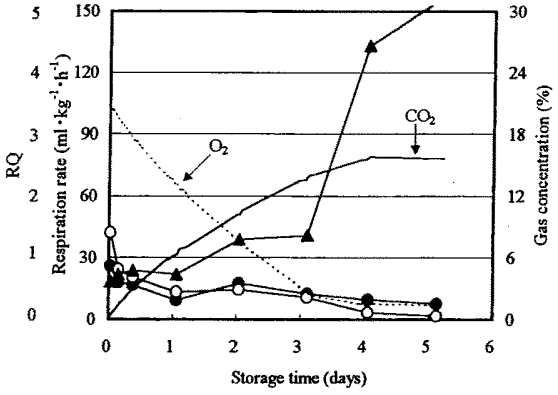

B: $30 \mu \mathrm{m}$ film at $5^{\circ} \mathrm{C}$

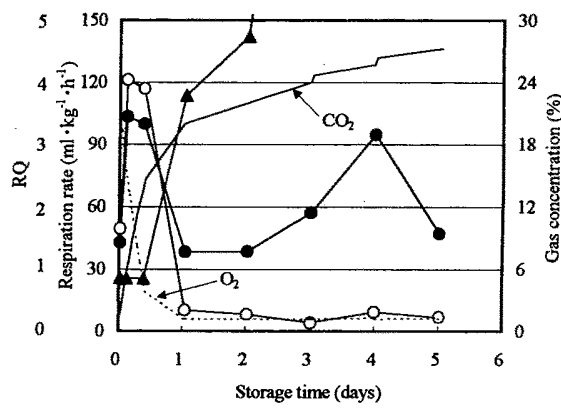

D: $30 \mu \mathrm{m}$ at $20^{\circ} \mathrm{C}$

Fig. 1. Changes in gas concentration, respiration rate and $R Q$ of fresh-cut cabbage in VC treatments at 5 and $20^{\circ} \mathrm{C}$. (O) represents $\mathrm{CO}_{2}$ production rate, (O) $\mathrm{O}_{2}$ consumption rate, $(\boldsymbol{\Delta})$ respiratory quotient $(\mathrm{RQ})$. Solid and dashed lines denote the $\mathrm{CO}_{2}$ and $\mathrm{O}_{2}$ concentrations, respectively.

oxygen. For the effect of cutting mode, there were no significant differences in changes in gas concentration and respiration rate between $\mathrm{PC}$ and $\mathrm{VC}$ treatments at $5{ }^{\circ} \mathrm{C}$ during storage (Fig. 1A-1B and Fig. 2A-2B). At $20^{\circ} \mathrm{C}$, the respiration rate were much higher in $\mathrm{VC}$ treatments than that in $\mathrm{PC}$ treatments, especially for the $\mathrm{CO}_{2}$ production rate (Fig. 1C-1D and Fig. 2C-2D).

MAP can be beneficial in maintaining quality of the fresh-cut product (Gorny, 1997). The suitable gas mixture for MAP has been based on that recommended for the whole commodity (Saltveit, 1997). Fresh-cut products probably can tolerate more extreme levels of $\mathrm{O}_{2}$ and $\mathrm{CO}_{2}$, because they do not have as much cuticle or skin to restrict gas diffusion, and the distance of gas diffusion from center to outside of fresh-cut product is much less than that for the whole commodity (King, et al., 1989). It was also reported that an additional benefit of MAP may be attained by actively flushing the package with the desired gas rather than allowing the MAP to develop naturally since the marketing period of fresh-cut product is relatively short (Bai, et al., 2001). In the present study, fresh-cut cabbage has much higher respiratory activity to consume $\mathrm{O}_{2}$ and produce $\mathrm{CO}_{2}$ quickly. 


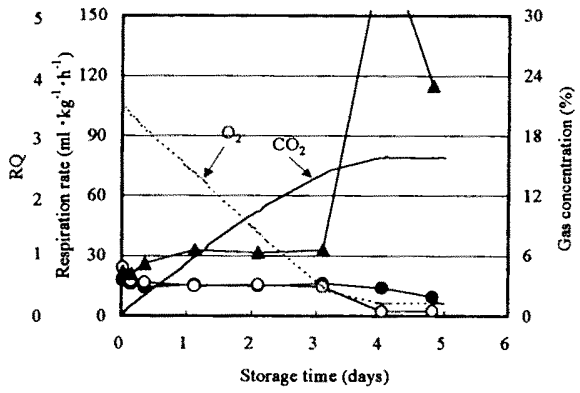

A: $25 \mu \mathrm{m}$ film at $5^{\circ} \mathrm{C}$

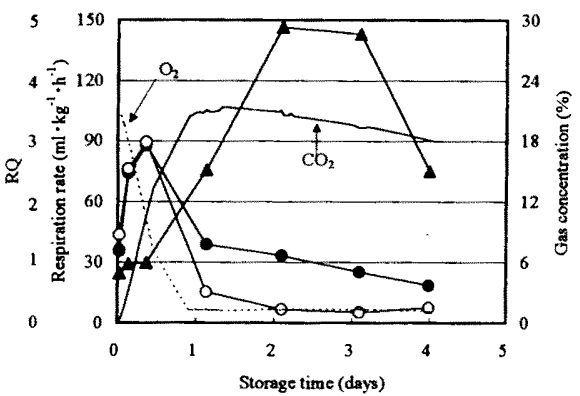

C: $25 \mu \mathrm{m}$ film at $20^{\circ} \mathrm{C}$

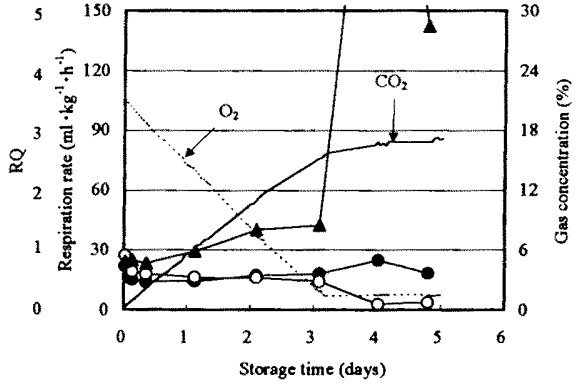

B: $30 \mu \mathrm{m}$ film at $5^{\circ} \mathrm{C}$

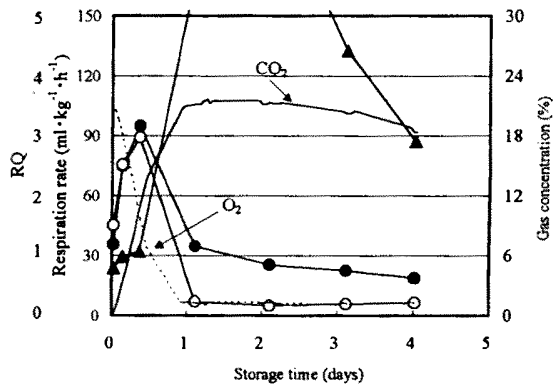

D: $30 \mu \mathrm{m}$ film at $20^{\circ} \mathrm{C}$

Fig. 2. Changes in gas concentration, respiration rate and $R Q$ of fresh-cut cabbage in $P C$ treatments at 5 and $20^{\circ} \mathrm{C}$. (O) represents $\mathrm{CO}_{2}$ production rate, $(\mathrm{O}) \mathrm{O}_{2}$ consumption rate, $(\boldsymbol{\Delta})$ respiratory quotient $(\mathrm{RQ})$. Solid and dashed lines denote the $\mathrm{CO}_{2}$ and $\mathrm{O}_{2}$ concentrations, respectively.

Anaerobic respirations were occurred after 3 days of storage at $5{ }^{\circ} \mathrm{C}$ and after 1 day of storage at $20^{\circ} \mathrm{C}$. It induced anaerobic respiration and higher $\mathrm{CO}_{2}$ damage to result in browning and development of off-flavors. Respiration rates of fresh-cuts generally were higher than the intact product. Although benefits may occur with modified atmosphere, the extinction point of the fresh-cut products must be recognized to avoid anaerobic respiration (Ko, et al., 1996).

Fresh-cuts generally are much more perishable than intact products because they have been subjected to severe physical stress, such as peeling, cutting, slicing, shredding, trimming and removal of protective cells. Consequently, fresh-cuts probably should be held at a lower temperature than that recommended for intact commodities. Temperature of $0^{\circ} \mathrm{C}$ is in most case preferable. However, this is in most cases economically not achievable. Temperature between 5 and $10^{\circ} \mathrm{C}$ is more commonly found in practice. The temperature effects on the tissue metabolism and biochemical reactions significantly, it is also of major important to maintain low temperature to prevent microbial growth. It suggests that it is important for handling and storing fresh-cut cabbage at lower temperature or near $0^{\circ} \mathrm{C}$, if the product is not sensitive to chilling injury. 


\section{Ascorbic acid}

Fig. 3 shows changes in ascorbic acid contents in fresh-cut cabbage at $5{ }^{\circ} \mathrm{C}$ during storage. TAA, AA and DHAA were increased in PC treatments for 3 days, and then decreased. In the $\mathrm{VC}$ treatments, the results were similar to $\mathrm{PC}$ treatments, they increased for 4 days and then decreased. But the increase of TAA from $32.4 \mathrm{mg} \cdot 100 \mathrm{~g}^{-1}$ fresh weight (FW) to $43.3-45.8 \mathrm{mg} \cdot 100 \mathrm{~g}^{-1} \mathrm{FW}$ was higher in $\mathrm{PC}$ treatments than that from $30.6 \mathrm{mg} \cdot 100 \mathrm{~g}^{-1} \mathrm{FW}$ to $34.7-36.3 \mathrm{mg} \cdot 100 \mathrm{~g}^{-1} \mathrm{FW}$ in VC treatments.

Fig. 4 shows changes in ascorbic acid contents in fresh-cut cabbage at $20^{\circ} \mathrm{C}$ during storage. TAA, AA and DHAA were increased and then decreased. The increase of TAA was less than that at $5^{\circ} \mathrm{C}$ (Fig. 3). But increase of DHAA was more significant than the increase at $5^{\circ} \mathrm{C}$. AA level is the result of the difference between AA production (biosynthesis or regeneration from $\mathrm{DHAA}$ ) and $\mathrm{AA}$ oxidation. If the rate of $\mathrm{AA}$ oxidation is higher than the rate of AA production, then AA content decreases (Zerbini, et al., 2002). In the present study, increase of DHAA was significant at $20^{\circ} \mathrm{C}$, indicating that the oxidation rate was higher than that at $5^{\circ} \mathrm{C}$. It demonstrated that activity of ascorbate oxidase was higher at $20^{\circ} \mathrm{C}$ than that at $5^{\circ} \mathrm{C}$. The significant decrease of AA after storage 3 days, it was due to oxidation of AA by ascorbate oxidase following tissue damage or by the reaction of AA with phenolic substances during storage. It could be also assumed that the role of AA as $\mathrm{S}$ reducing power in respect to de nova synthesis of polyphenols is pos-

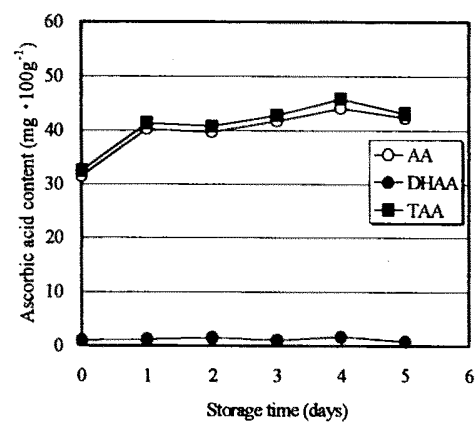

A: VC $25 \mu \mathrm{m}$ film

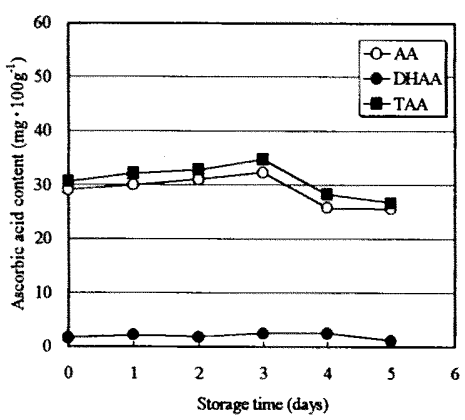

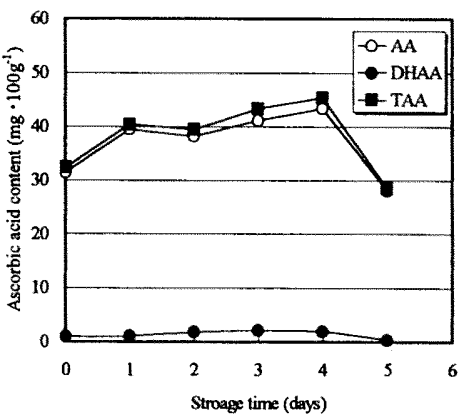

B: VC $30 \mu \mathrm{m}$ film

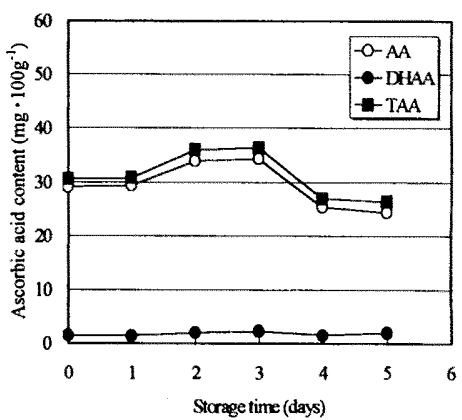

Fig. 3. Changes in ascorbic acid contents in VC and PC treatments at $5^{\circ} \mathrm{C}$ 


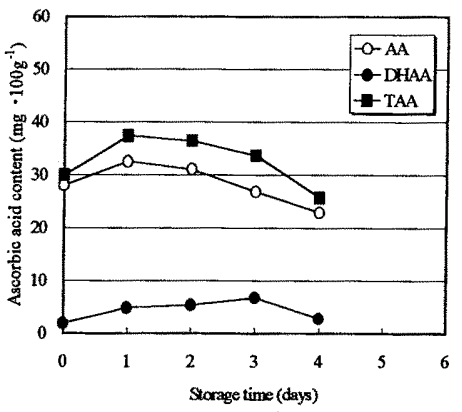

A: VC $25 \mu \mathrm{m}$ film

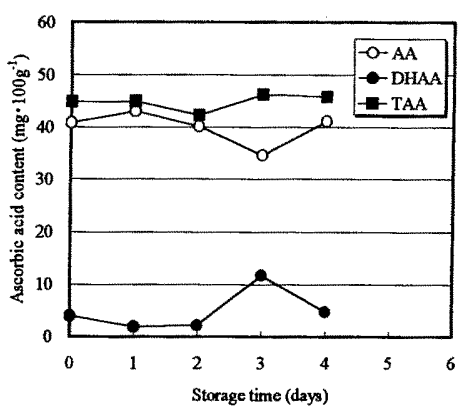

C: PC $25 \mu \mathrm{m}$ film

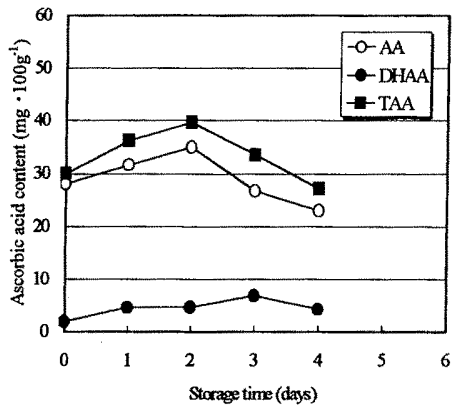

B: VC $30 \mu \mathrm{m}$ film

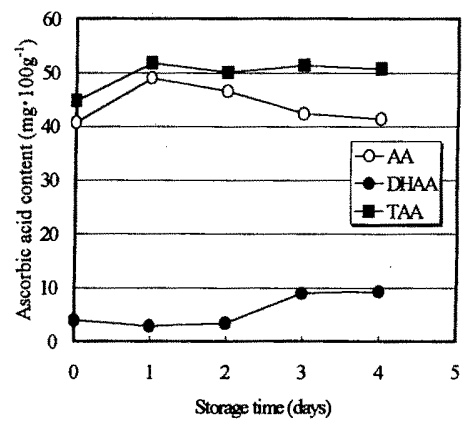

D: PC $30 \mu \mathrm{m}$ film

Fig. 4. Changes in ascorbic acid contents in $\mathrm{VC}$ and $\mathrm{PC}$ treatments at $20^{\circ} \mathrm{C}$

sible. Ascorbic acid plays an important part in the defence mechanism against free radicals which induce peroxidation (Barth, et al., 1993). AA can be easily oxidised to dehydroascorbic acid, the latter in turn can either be reduced.

\section{Sensory evaluation}

Sensory evaluation of fresh-cut cabbage at $5^{\circ} \mathrm{C}$ was shown in Table 1 . Visual appearances were not changed much during storage of 4 days in all treatments. Off-flavor was slightly occurred after 3 days by anaerobic respiration. At $20^{\circ} \mathrm{C}$ (Table 2), appearances were not changed in VC treatments, but browning was occurred after 3 days. In PC treatments, the browning was occurred much significantly. For the flavor, off-flavor was occurred after 1 day and appeared more serious in PC treatments after storage of 3 days. It seems that the changes in appearance and flavor depend on physiological changes associated with cutting direction. It was considered that the callus in wounded place of cabbage was formed quicker in VC treatments than PC treatments. Because the respiration rate were much higher in $\mathrm{VC}$ treatments than that in $\mathrm{PC}$ treatments, especially for the $\mathrm{CO}_{2}$ production rate at $20^{\circ} \mathrm{C}$. Moreover, the cutting wound area was large and tissue sap seeped much from vascular bundle of cabbage in PC treatments. The seeped tissue sap in PC treatments can induce obvious browning and off-flavor. It seems that thickness 
Table 1. Sensory evaluation of fresh-cut cabbage at $5^{\circ} \mathrm{C}$

\begin{tabular}{ccccccc}
\hline \multirow{2}{*}{ Item } & Cutting treatment & \multicolumn{5}{c}{ Storage period (day) } \\
\cline { 3 - 6 } & & 0 & 1 & 2 & 3 & 4 \\
\hline \multirow{3}{*}{ Appearance } & VC-25 & - & - & - & - & - \\
& VC-30 & - & - & - & - & - \\
& PC-25 & - & - & - & - & - \\
& PC-30 & - & - & - & - & - \\
\hline \multirow{6}{*}{ Flavor } & VC-25 & - & - & - & + & + \\
& VC-30 & - & - & - & + & + \\
& PC-25 & - & - & - & + & + \\
& PC-30 & - & - & + & + & + \\
\hline
\end{tabular}

Table 2. Sensory evaluation of fresh-cut cabbage at $20^{\circ} \mathrm{C}$

\begin{tabular}{ccccccc}
\hline \multirow{2}{*}{ Item } & Cutting treatment & \multicolumn{5}{c}{ Storage period (day) } \\
\cline { 3 - 6 } & & 0 & 1 & 2 & 3 & 4 \\
\hline \multirow{3}{*}{ Appearance } & VC-25 & - & - & - & - & - \\
& VC-30 & - & - & - & - & - \\
& PC-25 & - & - & - & ++ & +++ \\
& PC-30 & - & - & - & ++ & +++ \\
\hline \multirow{3}{*}{ Flavor } & VC-25 & - & + & + & + & + \\
& VC-30 & - & + & ++ & ++ & ++ \\
& PC-25 & - & + & + & ++ & +++ \\
& PC-30 & - & + & + & ++ & +++ \\
\hline
\end{tabular}

of film has less effect on the respiration and quality of fresh-cut cabbages. It was suggested that the better quality can be obtained from $\mathrm{VC}$ treatments at $5^{\circ} \mathrm{C}$.

\section{CONCLUSIONS}

The respiration rates, quality attributes of fresh-cut cabbage were determined in MAP with 25 and $30 \mu \mathrm{m}$ OPP films in thickness at 5 and $20^{\circ} \mathrm{C}$ during storage. The respiration rates of fresh-cut cabbages were suppressed under the condition of decreasing $\mathrm{O}_{2}$ and increasing $\mathrm{CO}_{2}$ concentrations. It was not found the effects of cutting mode (VC and $\mathrm{PC}$ treatments) and thickness of film on the respiration at $5^{\circ} \mathrm{C}$. But the respiration rate were much higher in $\mathrm{VC}$ treatments than that in $\mathrm{PC}$ treatments, especially for the $\mathrm{CO}_{2}$ production rate at $20^{\circ} \mathrm{C}$. The results also showed that a shift from aerobic to anaerobic respiration was occurred under $1.2-1.5 \% \mathrm{O}_{2}$ levels for fresh-cut cabbage. TAA, AA and DHAA were increased by AA biosynthesis initially and then decreased by higher rate of AA oxidation. For sensory evaluation, there were no differences in appearance and flavor for cutting mode and thickness of film at $5^{\circ} \mathrm{C}$. The better appearance and flavor appeared in VC than PC treatments for cutting mode and thickness of film at $20^{\circ} \mathrm{C}$. It suggests that better quality could be obtained from the combination of $\mathrm{VC}$ treatments and low 
temperature of $5^{\circ} \mathrm{C}$ regardless of thickness of OPP film during storing and marketing

\section{ACKNOWLEDGEMENTS}

The authors would like to thank Sumitomo Bakelite Co., Ltd for providing the OPP film.

\section{REFERENCES}

Akimoto, K. and S. Maezawa 1997 A new method for estimating respiration rate of fruits and vegetables in modified atmosphere packaging. J. of the J. Soc. Agri. Machineary, 59(1): 109-116

Bai, J.H., R.A. Saftner, A.E. Watada and Y.S. Lee 2001 Modified atmosphere maintains quality of fresh-cut cantaloupe (Cucumis melo L.). J. Food Sci, 66: 1207-1211

Barth, M. M., E. L. Kerbel, S. Broussard and S. J. Schmidz 1991 Modified atmosphere packaging protects market quality in broccoli spears under ambient temperature storage. J. Food Sci., 58: 1070-1072

Gorny, J. R., M. I. Gil and A. A. Kader 1998 Postharvest physiology and quality maintenance of fresh-cut pears. Acta Hort., 464: 231-236

Gorny, J. R. 1997 Summary of CA and MA requirements and recommendations for fresh-cut (minimally processed) fruits and vegetables. Proceedings of Seventh International Controlled Atmosphere Conference, Vol. 5. Postharvest Outreach Program, University of California, Davis, CA: $30-66$

Guerzoni, M. E., A. Gianotti and M. R.Corbo and M. Sinigalia 1996 Shelf-life modeling for fresh-cut vegetables. Postharvest Biol. Technol., 9: 195-207

Kader, A. A. 1986 Biochemical and physiological basis for effects of controlled and modified atmospheres on fruits and vegetables. Food Technol., 5: 99-104

Kato-Guchi, H. and A. E. Watada 1997 Effects of low-oxygen atmosphere on ethanolic fermentation in fresh-cut carrots. J. Am. Soc. Hort. Sci., 122: 107-111

King, A. D. and H. R. Bolin 1989 Physiological and microbiological storage stability of minimally processed fruits and vegetables. Food Technol., 2: 132-135

Ko, N. P., A. E. Watada, D. V. Schlimme and J. C. Bouwkamp 1996 Storage of spinach under low oxygen atmosphere above the extinction point. J. Food Sci., 61: 398-400+406

Lopez-Briones, G., P. Varoquaux, Y. Chambroy, J. Bouquant, G. Bureau and B. Pascat 1992 Storage of common mushroom under controlled atmospheres. Inter J Food Sci Technol., 27: 493-505

Rosen, J. C. and A. A. Kader 1989 Postharvest physiology and quality maintenance of slice pear and strawberry fruits. J. Food Sci., 54:656-659

Senesi, C., M. Prinzivalli, K. Sala and M. Gennari 2000 Physicochemical and microbiological changes in fresh-cut green bell peppers as affected by packaging and storage. Ital. J. Food Sci., 12: 55-64

Sltveit, T. J. 1997 Summary of CA and MA requirements and recommendations for harvested vegetables. Proceedings of Seventh International Controlled Atmosphere Conference, Vol. 4. Postharvest Outreach Program, University of Califomia, Davis, CA: 98-117

Watada, A. E., N. P. Ko and D. A. Minott 1996 Factors affecting of fresh-cut horticultural products. Postharvest Bio. Technol., 9: 115-125

Zerbini, P. E., A. Rizzolo, A. Brambilla and P. Cambiaghi 2002 Loss ascorbic acid during storage of conference pears in relation to the appearance of brown heart. J. Sci. Food Agric., 82: 1007-1013 